\title{
Financing of Public Works as a Form of Temporary Legal Employment of Unemployed Citizens in Ukraine
}

Submitted on 03/12/18, $1^{\text {st }}$ revision 08/02/19, $2^{\text {nd }}$ revision 16/03/19, accepted 17/04/19

\author{
Nataliya P. Mokrytska ${ }^{1}$, Mariya S. Dolynska² ${ }^{2}$ Iryna O. Revak ${ }^{3}$
}

\begin{abstract}
:
Purpose: The article deals with the essence and structure of the state mechanism for the organization and conduct of public works. Special features of forming legal and socioeconomic conditions of implementing the right to employment of unemployed persons are examined.

Design/methodology/approach: The principal role in the organization of public works belongs to state institutions authorized to manage flows of funds. The key entities making managerial decisions on the organization of public works and their financial planning are state authorities (local state administrations), local self-government bodies (executive committees of village, town, and city councils), and territorial bodies of central executive body (bodies of State Employment Service). The source of public works financing is local budgets, financial resources of employers, the Fund of compulsory state social unemployment insurance. Findings: The basis for local authorities' decision-making is various territorial employment programs approved by the relevant local authorities.

Practical Implications: In order to ensure the effective conduct of public works, it is proposed to amend the norms of authoritative and regulatory acts resulting in duplication of pecuniary liabilities by means of equal distribution between the local budget and the Fund of compulsory state social unemployment insurance.

Originality/value: Public works are regarded as a social service that is available to unemployed citizens through the payment of insurance fees during their employment.
\end{abstract}

Keywords: Family businesses, corporate governance, rational behaviour, regulations.

JEL Codes: E60, H55, H83.

Paper type: Research article.

\footnotetext{
${ }^{1}$ Faculty of Law, Lviv State University of Internal Affairs, corresponding author, 1981phd@gmail.com

${ }^{2}$ Faculty of Law, Lviv State University of Internal Affairs, m.s.dolynskaa@gmail.com

${ }^{3}$ Faculty of Management and Economic Security, Lviv State University of Internal Affairs, irarevakk@gmail.com
} 


\section{Introduction}

For a long time, in many European countries, paid public works were used as a programmed, predetermined and planned means of sharp reduction of unemployment and exceptional improvement of macroeconomic indices during financial crises, natural cataclysms and massive population migration by involving people in simple unskilled jobs that the local community needed.

In particular, in Latvia, which was hard hit by the global financial crisis, in the period from 2008 to 2010 the GDP (Gross Domestic Product) dropped by 21 per cent, while from 2008 to 2009 the poverty rate increased from 10.1 per cent to 18.1 per cent, and the employment rate dropped by 11.2 per cent. In response to these problems, Latvia spent an amount, which was equivalent to 22 billion forints (or about 73 million euros) for its program of public works in the period from 2009 to 2011 that totaled 0.25 per cent of GDP in Latvia and 2.5 times exceeded the expenditures on social security of the population (Kálmán, 2015, p. 47).

The organization of paid public works requires the significant financial resources and the ability to use them effectively for creating legal and socio-economic conditions for implementing the right to protection against unemployment. It is preceded by a rather voluminous financial planning activity of the relevant state institutions. The result of effective work of the latter is the driving force, which affects the financial support for carrying out public works, their management and control over their use. The multifaceted nature of such predictable activity in the organization of public works is expressed in many components characterizing such interrelated categories as the form and content, the terms and procedure for financial planning of public works. It contributed to the relevance of the chosen topic of research.

At the same time, public works are also regarded as a social service that is available to unemployed citizens through the payment of insurance fees during their employment. The unification of financial resources of the state or local authorities with insurance funds (payments) enables to increase the efficiency of public works and ensure their transformation into a permanent source of funds irrespective of financial indices of the state. Therefore, the organization of public works requires the involvement of the institutions responsible for insurance funds in the planning activity.

It should be noted that ensuring the proper organization of public works requires a research of theoretical and methodological foundations of so-called "financial planning". This concept of the financial science, which is comprehensively investigated and regarded as a specific process, gets a completely different interpretation in terms of the state mechanism of assistance in employment at paid public works. Financial planning plays a determinant role at the stage of the predicted and premeditated decision or decisions; and the amount of cash security for public works, their management and control over their application depend on it. 
It is necessary to clarify the form and content of financial planning of public works as they contribute to an integral sight of the problem of the financial system of budget at the stage of its strategic formation. We see the need to distinguish some features of financial planning as process, which could be the starting points of the research of its characteristics in the state mechanism for the organization and implementation of public works.

\section{Literature Review}

Comprehensive study of the problems of managing public works in the countries, determination of the organizational and institutional structures, goals, amount and models of financing this social protective means have been in sight of scientists for a long time (Bertrand et al., 2017; Gehrke and Hartwig, 2015; 2018; Zimmermann, 2014). The exclusivity of each model of financial planning, depending on the chosen country, is investigated by such scientists as Subbarao et al. (2013). Scientists point out that "much of the success and quality of a public works program depends on solid program design. A successful design includes several features that reflect the program's goals and are adapted to the country's circumstances and constraints" (Subbarao et al., 2013). One of such components is "the role of institutions and delivery models" (Subbarao et al., 2013, p. 48).

The scientific analysis, which is based on data from 32 countries implementing a total of 40 public works programs, indicates that the breakdown of Implementing Institutions is as follows: the percentage of central and local government is $36 \%$, regional and district government $-21 \%$, and only $7 \%$ is a combination of government entities (Subbarao et al., 2013, p. 52). Thus, the principal role in the organization of public works belongs to centralized regulated institutions that are in authority to manage flows of funds. At the same time, unemployed citizens need public works and the financial mechanism for their implementation needs to attract additional financial resources, by which the social insurance system of the same citizens owns. In particular, in accordance with the report of the European Job Mobility Laboratory, which has been prepared for the European Commission, cooperation between public employment service and work providers is based on productive financial planning for public works (Fuller et al., 2013).

Nevertheless, it is necessary to clarify the issues of the planned activities of the organization of public works, without which it is impossible to ensure this measure of promoting employment.

The purpose of the article is to analyze the planned activities of public works organization with the example of Ukraine as an important element of state policy in the field of promoting employment of the population, preventing and overcoming long-term unemployment. The results of the research are aimed at determining the effectiveness of public works programs, which contribute to carrying out public works. 


\section{Research Methodology}

System analysis methodology is applied in the study. Therefore, the relevant processes are analyzed in the interconnection and development context. The multilevel concept of problem cognition, which include a wide range of different methods, is used. The methods of scientific abstraction, induction and deduction, analysis and synthesis, historical, logical and other theoretical methods cognition of socio-economic phenomena, objects and processes cognition are applied to formulate scientific provisions and clarify the economic law and public administration theory terminology apparatus. Comparative and hierarchical methods are used to contrast scientific approaches to the understanding of "economic work" and "implementation of the unemployed persons' right to employment" concepts. System-structural and axiological methods are embraced to determine the internal architecture of public institutions that make managerial decisions on the organization of public works and their financial planning. The methods of theoretical generalization, systematization and grouping are exploited in the research of the methodical approaches to the financing public works sources determination. Economic and statistical methods of information collection and processing, comparisons and generalizations are used to evaluate financial indicators that determine the costs of organizing public works in various normative documents at the local governments (local authorities) level. The comparative method is applied to collate the funding of the social work organization in different territorial communities. The abstract-logical method is used in the synthesizing and summing up the results.

The purpose of the research is to ground the theoretical and methodological provisions and to develop applied guidelines concerning the organization and financing of public works as a form of temporary legal employment of unemployed people in Ukraine. In order to achieve the above mentioned goal the following tasks should be solved: to analyze the essence and organizational structure of the state organization mechanism and public works realization; to consider the peculiarities of the formation of legal and socio-economic conditions for the implementation of the right to employment of unemployed persons; to give a systemic assessment of state institutions that take managerial decisions on the organization of public works and their financial planning; to identify sources of public works funding; to propose to make changes to the regulatory and administrative acts regulating the financing of public works in Ukraine.

\section{Organizational Structure and Sources of Public Works Financing}

Paid public works can be defined as a temporary form of implementation of the right to work in Ukraine; they are proposed by territorial bodies of the State Employment Service as one of the options for temporary employment on legal grounds in the interests and in favor of the territorial community by concluding a fixed-term employment contract in order prescribed by law (Law of Ukraine No. 5067-VI, 2012; Resolution of the Cabinet of Ministers of Ukraine No. 175, 2013). 
In Ukraine, the procedure for organizing and conducting public works is established annually in accordance with the territorial employment programs of the population and other relevant programs based on the decision of local authorities, namely, local state administrations and executive committees of village, town and city councils. These bodies determine the types of work, employers planning the organization of such works and inform about their decision (Law of Ukraine No. 5067-VI, 2012; Resolution of the Cabinet of Ministers of Ukraine No. 175, 2013). At the same time, local authorities inform territorial authorities of the State Employment Service in regions, cities and districts about the content of the decision on the organization of public works indicating the amount of funds for financing their organization (Law of Ukraine No. 5067-VI, 2012; Resolution of the Cabinet of Ministers of Ukraine No. 175, 2013).

However, the decision on the organization of public works adopted by the local authorities becomes obligatory for each employer only in case of conclusion of a fixed-term contract on the organization of public works and the financing of their organization. The territorial body of the State Employment Service and the employer are the parties of this contract. When the employer is a local authority, the contract is concluded between the local authority and the territorial authority of the State Employment Service (Law of Ukraine No. 5067-VI, 2012; Resolution of the Cabinet of Ministers of Ukraine No. 175, 2013).

Thus, the types of employers determined in the decision of local authorities are only an element of financial planning activity, and at this stage it cannot have a binding nature for employers. The financial planning involves taking annual managerial decision on the organization of public works. Two entities - state authorities (local state administrations) and local self-government bodies (executive committees of village, town, and city councils) should be involved in this process. At the stage of familiarization with the corresponding decision, another entity of public administration - the territorial body of the central executive authority, which implements the state policy in the field of employment and labor migration, is introduced in this process (Law of Ukraine No. 5067-VI, 2012; Resolution of the Cabinet of Ministers of Ukraine No. 175, 2013). It refers to the territorial bodies of the State Employment Service.

Therefore, the organization of public works in Ukraine depends on coordinated and mutually agreed actions of the authorities, especially at the stage of their adoption of appropriate managerial decisions. However, employers, without whom it is impossible to organize public works, take part in financial planning for public works organization voluntarily, on their own will, only on a contractual basis and only at the stage of putting a managerial decision into operation. The achievement of the goals and tasks of public works depends on a well-organized management of financial expenditures. Therefore, we believe that the determination of the financial support of this measure of employment promotion is a necessary component of the decision on the organization of public works, without which such a decision cannot be considered 
as a financial document.

In Ukraine, the source of funding for public works may be any financial resources not prohibited by law. First, it is the funds of local budgets and employers. The distribution of financial expenditures on the organization of public works also affects the subjects who need employment and participate in paid public works. They are persons registered in the territorial bodies of the State Employment Service, who are looking for work and ready to begin its execution by concluding a fixed-term employment contract with an employer. Organization of public works for the registered unemployed is carried out at the expense of local budgets and (or) the Fund of compulsory state social unemployment insurance of Ukraine. The attraction of the funds of the latter is due to the fact that public works are a social service, which is covered by social insurance expenditures.

Consequently, we can conclude that none of these financial sources can be predetermined as binding, without which the financial planning of paid public works would be impossible. The only predetermined financial resource for the organization of public works is the resources of the Fund of compulsory state social unemployment insurance of Ukraine. In that case public works are organized for workers who are in a state of so-called "involuntary unemployment". Unlike the registered unemployed they need to work, because due to the suspension (reduction) of production, the statutory duration of their working hours reduced to $50 \%$ (Law of Ukraine No. 5067VI, 2012; Resolution of the Cabinet of Ministers of Ukraine No. 175, 2013).

However, public works can also be funded from other sources, not prohibited by law. The legislator does not specify "other sources" in addition to the wages fund of the employer. In our opinion, this gap should be eliminated by determining which additional sources can be used in the organization of public works. In order to provide a basis, it is advisable to take advantage of the foreign experience of lawmaking. In particular, the legislation of the Republic of Moldova stipulates investments, grants, sponsoring means aimed at the community development (Resolution of Cabinet of Ministers of the Republic of Moldova No. 862, 2003). Thus, the territorial limitation of funding sources is not considered, but the special-purpose financing clearly indicates the movement direction of these funds.

The resources of the Fund of compulsory state social insurance, although they are not included in the State Budget of Ukraine (Law of Ukraine No. 1533-III, 2000), are an integral component of the financial system of Ukraine, which are formed mainly by insurance fees of employers and employees. The resources of this Fund are a very important financial source for organizing and conducting public works. Meanwhile, the only management decision, which determines the amount of expenditures for active measures to promote employment of the population, is the budget of the Fund that is approved by its decision and confirmed by the Cabinet of Ministers of Ukraine.

The State Employment Service constantly provides information about the state of 
employment. For example, UAN 76,949,300 was planned for the organization of public works throughout the territory of Ukraine in 2016. That amount greatly exceeds the expenditures of previous years (Resolution of the Cabinet of Ministers of Ukraine No. 414, 2016). UAH 69,297,600 was spent from these funds; the sum total indicates that the planned expenditures are $90.1 \%$ (Resolution of the Board of the Compulsory State Social Insurance Fund No. 140, 2017). In 2017, 220,300 citizens were involved in public works and other temporary works, and 216,600 of them were registered as the unemployed.

\section{Financing of Public Works as Local Authority Revenue Expenditure}

The purposeful activity concerning the organization of public works also depends on the proper organization of allotting and distributing the funds of the local budget. At the same time, the volume of expenditures and the share of local budgets in total expenditures on the organization of public works increased (in $2017-59.4 \%$ versus $48.7 \%$ in 2016) (Resolution of the Board of the Compulsory State Social Insurance Fund No. 173, 2018). The basis for local authorities' decision-making is the territorial employment program of the population and other relevant programs that relate to the predicted state of the labor market and the changes that are necessary to improve the situation in this area. In particular, in Lviv there is the Program of organization and conduction of public and other temporary works in 2018-2022 (Resolution of Lviv City Council No. 2788, 2017).

The financial support of these territorial programs takes place at the stage of approval of the local budget in order established by law. The decision approving the fund of local self-government bodies establishes a sum of money allocated for financing of the corresponding local programs, a chief administrator and a responsible executor determined by the temporary classification of expenditures. For example, in Lviv, expenditures on the organization of public works were planned to be UAH 1,018,100; the largest amount was allocated to the Department of Economic Development, the rest of the amount was distributed among the district state administrations of the city (Resolution of Lviv City Council No. 2585, 2017).

Financial indices may be included in the list of expenditures of the city budget, which is also a component of the local budget. However, their cost value should correspond to the one that is fixed in the section on the financing of the relevant territorial programs. In particular, in 2016, the local budget of Khmelnytskyi provided funds for co-financing the remuneration of employees sent by the employment service to perform public works in the Department of labor and social protection of population in the amount of UAH 110,000. The Executive Committee of Khmelnytskyi City Council of Khmelnytskyi region is the chief administrator of these funds (Resolution of Khmelnitskyi City Council No. 1, 2015). In Sumy, the Department of social protection of population of Sumy city council has allocated UAH 160,429 for public works organization this year (Resolution of Sumy City Council No. 143-MR, 2015). Within the City Target Program "Care. Meet the people of Kyiv" for 2016-2018 in 
Kyiv in 2016, the organization and implementation of public works were funded by the redistribution of funds among Kyiv district administrations (Resolution of Kyiv City Council No. 61/61, 2015). The city budget of Dnipro for 2016 provided subventions to Dnipro district administrations to perform the measures of the Employment Program of Dnipropetrovsk for 2013-2017, including UAH 419,999 to organize and conduct public works (Resolution of Dnipro City Council No. 3/5, 2016).

Thus, the unified financial document that reflects the financial indices of the predicted budget expenditures is the local authority revenue expenditure for the current calendar year (the corresponding fiscal year). It is approved by the relevant decision of the authorized subject. It should be noted that the competence of the local state administration and the executive committee of village, town and city councils does not include the issue of approval of local budgets. It is the authority of local selfgovernment bodies - village, town or city councils.

Therefore, the local budget can be considered as a source of public works financing, which specifies the amount of money, which is allocated to the organization of public works and identical with cost value of the relevant territorial program financing. Such a program can be called a program of organization of public and other works of a temporary nature or it can be comprehensive and cover other issues of employment. It has been operating for several years. The decision on its approval is taken by the relevant local self-government body.

In our opinion, it would be advisable to approve a separate territorial program - the Program for the organization and implementation of public works. In this way, the local budget can clearly track the amount of money that will be allocated in a particular fiscal year for public works financing. The decision on approval of the local budget, which is adopted by local authorities, is a component of those documents that should be taken into account when determining the elements of financial planning of public works organization. After all, financial indices of the predicted budget expenditures are displayed here, and the program of public works organization is implemented by means of them.

\section{Financial Planning in Regulatory Acts of Local Bodies}

The adoption of the local budget creates a financial basis for the formation of the expenditure plan of organization and implementation of public works with the participation of local self-government bodies. However, there is no established unified approach to the term of the adoption and presentation of the content of relevant decisions on the organization of public works.

The study of regulatory acts of executive committees of local self-government bodies demonstrates that they are obliged to solve the issues of types of employers and works to be implemented. They also attract the registered unemployed to public works. 
It is clear that such issues cannot be solved independently by local authorities, and therefore, the proposals of territorial bodies of the State Employment Service are taken into account for effective implementation of the employment promotion measure. The next compulsory component of the decision on the organization of public works, which distinguishes it as a document of financial planning, is establishment of the amount of funds necessary to finance the organization of public works.

This establishment takes place in a different way. The projected distribution of funds may be carried out by means of a clearly defined monetary amount, a general indication of the appropriate source of funding, with the indication of their chief administrators or even without solving the issue of their funding.

In case when the decision of the executive committee of the local self-government body determines a financial plan for covering expenditures for public works, it corresponds to the amount of funds by means of which it is planned to cover the implementation of public works in accordance with the local budget. For example, the amount of the local budget expenditures - UAH 1,018,010 - was determined in the Resolution of Lviv City Council "On the organization and conduct of public and other temporary works in Lviv for 2018" (Resolution of Lviv City Council No. 81, 2018), it fully corresponds to the amount allocated for financing in 2018 of the Program of organization and conduct of public and other temporary works in Lviv for 2018-2022.

The study of administrative decisions of local authorities in this sphere also proves that acts should elucidate financial indices of predicted expenditures not only of the local budget, but also the Fund of compulsory state social unemployment insurance or other sources. In particular, in the Resolution of Lviv City Council "On the organization and conduct of public and other temporary works in Lviv for 2018", the amount of social funds is equal to the amount of funds allotted by the local budget (Resolution of Lviv City Council No. 81, 2018). It turns out that the decision of executive committees of local councils on the organization and conduct of public works acquires common, beforehand-agreed features.

In our opinion, an attempt to combine the financial obligations of all subjects involved in the process of organizing public works within the corresponding territorial community in the authoritative and regulatory act, called the decision on the organization of public works, can be successful only if the majority of organizational aspects were approved before this decision. It requires involving the territorial bodies of the State Employment Service in the discussion and decision-making process. They manage and dispose of the financial resources of the Fund of compulsory state social unemployment insurance of Ukraine within the approved budget of the Fund (Law of Ukraine No. 5067-VI, 2012).

At the same time, the territorial bodies of the State Employment Service authorized to cooperate with employers as to organization of public works on a contractual basis do not participate in taking the decision on the organization of public works. 
Consequently, the obligatory nature of the document would confirm the common achievement of the consent of all involved subjects at the stage of financial planning. The main purpose of the process of negotiating is the allocation of financial expenditures on the organization of public works in the way of a specific proposal defined by entities. The subjects are informed in advance about the content of the draft decision; they may submit proposals for the improvement of its content. In our opinion, such an approach involves logical consistency and reveals financial planning as coordination, coherence of successive actions, since it gives us an opportunity to determine the total amount of funds allocated within a certain region for public works.

Thus, a planned purposeful organizational activity should be carried out by each branch of the power structure. Its form is taking the decision on the organization of public works, which must specify the types of work and a list of employers planning the organization of such works and making the financial plan of covering expenditures for public works.

\section{Conclusion}

Public works are a planned measure of employment promotion that is implemented consistently in accordance with established rules and procedures. Public works need the proper financial planning of their organization in order to provide temporary legal employment of the unemployed based on the labor contract. The analysis of regulatory acts on the organization of financial planning of public works proves that they are conducted in Ukraine in accordance with a decentralized mixed management model of financial resources. There is an equal distribution of financial resources between local self-government bodies and territorial bodies of the State Employment Service. These entities represent two independent budgets - the local budget and the Fund of compulsory state social unemployment insurance.

It causes the necessity of equal distribution of obligations aimed at establishing not only the financial indices of the predicted budget expenditures - local budgets and the Fund of compulsory state social unemployment insurance, but also the normative definition of responsibilities for monitoring and financial reporting on the disposal of these financial resources in order to ensure the effectiveness of public works.

This scientific research contributes to analyze the basic aspects of the organization of paid public works in Ukraine and resolve several actual financial problems by means of such financial category as financial planning. It is proposed to consider the form of financial planning in terms of the authoritative and regulatory acts, the content of which is the financial indices of the predicted expenditures of the local budget, the Fund of compulsory state social unemployment insurance or other sources. It is proved that in Ukraine, the organization of public works involves the simultaneous adoption of two authoritative and regulatory acts, resulting in duplication of pecuniary liabilities in this field. In that case, only the decision on the organization of public works, adopted by the executive committees of village, town, and city councils, 
reflects the financial indices of budget expenditures, which substantiate the financial ability of local self-government bodies, and the system of social unemployment insurance to cover expenditures on organizing and conducting public works.

\section{References:}

Bertrand, M., Crépon, B., Marguerie, A. \& Premand, P. 2017. Contemporaneous and PostProgram Impacts of a Public Works Program: Evidence from Côte d'Ivoire.

Available at:

<https://openknowledge.worldbank.org/bitstream/handle/10986/28460/120065-WPPUBLIC-141p-Public-Works-CIV-Bertrand-Crepon-Marguerie-Premand-DraftMay17.pdf? sequence $=1 \&$ isAllowed $=\mathrm{y}>$

Fuller, A., Godfrey, E., Bros-Sabria C., Vidovic, H. \& Grabowska-Lusinska, I. 2013. Public works: how can PES contribute to increasing their value as an activation tool? European Job Mobility Laboratory.

Gehrke, E. \& Hartwig, R. 2015. How can public works programmes create sustainable employment? Discussion Paper. Available at: <https://www.diegdi.de/uploads/media/DP_11.2015.pdf>

Gehrke, E. \& Hartwig, R. 2018. Productive effects of public works programs: What do we know? What should we know? World Development, 107, 111-124.

Kálmán, J. 2015. The background and international experiences of public works programmes. In Focus, 1, 42-58.

Law of Ukraine No. 1533-III. 2000. On Compulsory State Social Unemployment Insurance. Available at: <http://zakon.rada.gov.ua/laws/show/1533-14?lang=en

Law of Ukraine No. 5067-VI. 2012. On Employment of Population. Available at: <http://zakon.rada.gov.ua/laws/show/en/5067-17>

Resolution of Cabinet of Ministers of the Republic of Moldova No. 862. 2003. On Approval of Access Procedures for Public Employment Measures. Available at: <http://lex.justice.md/document_rus.php?id=22E2750D:44CF4FF2>

Resolution of Dnipro City Council No. 3/5. 2016. On the city budget for 2016. Available at: $<$ http://dniprorada.gov.ua/rishennja-miskoi-radi-vid-30032016-35-pro-miskijbjudzhet-na-2016-rik>

Resolution of Khmelnitskyi City Council No. 1. 2015. On the city budget of Khmelnitskyi for 2016. Available at:

<http://www.khmelnytsky.com/index.php?option=com_content\&view=article\&id=2 8831\%3A01-q-2016-q\&catid=630\%3A-29122015\&Itemid=251>

Resolution of Kyiv City Council No. 61/61. 2015. On the city budget of Kyiv for 2016. Available at:

<http://kmr.ligazakon.ua/SITE2/1_docki2.nsf/alldocWWW/4C6347AB7F28C7DBC 2257F2B006DEA4E?OpenDocument>

Resolution of Lviv City Council No. 2585. 2017. On the city budget of Lviv for 2018. Available at: https://city-adm.lviv.ua/public-information/budget/lviv/2018>

Resolution of Lviv City Council No. 2788. 2017. Program of organization and conduct of public and other temporary works in Lviv for 2018-2022. Available at: <https://www8.cityadm.lviv.ua/inteam/uhvaly.nsf/(SearchForWeb)/2654F56E292ABF6FC2258202004 FD0A9>

Resolution of Lviv City Council No. 81. 2018. On the organization and conduct of public and other temporary works in Lviv for 2018. Available at: <https://www8.city- 
adm.lviv.ua/pool/info/doclmr_1.nsf/(SearchForWeb)/24EB8DCB62BC573AC2258 221003B1CE1?Open Document

Resolution of Sumy City Council No. 143-MR. 2015. On the city budget of Sumy for 2016. Available at: $<\mathrm{http} / / / \mathrm{www} \cdot \mathrm{meria}$. sumy.ua/index.php?do=cat\&category=mskiybyudzhet>

Resolution of the Board of the Compulsory State Social Insurance Fund No. 140. 2017. On Approval of Reports on the Results of the Activity of the Fund of Compulsory State Social Unemployment Insurance for 2016 and on the Execution of the Fund Budget for 2016. Available at: <https://www.dcz.gov.ua/sites/default/files/imce/postanova_140.pdf>

Resolution of the Board of the Compulsory State Social Insurance Fund No. 173. 2018. On Approval of Reports on the Results of the Activity of the Fund of Compulsory State Social Unemployment Insurance for 2017. Available at: <https://www.dcz.gov.ua/sites/default/files/postanova_no_173.pdf>

Resolution of the Cabinet of Ministers of Ukraine No. 175. 2013. On Approval of the Procedure for the Organization of Public and Other Temporary Works. Available at: <http://zakon.rada.gov.ua/laws/show/175-2013-\%D0\%BF?lang=en>

Resolution of the Cabinet of Ministers of Ukraine No. 414. 2016. On Approval of the Budget of the Fund of Compulsory State Social Unemployment Insurance. Available at: <http://zakon.rada.gov.ua/laws/show/414-2016-\%D0\%BF>

Subbarao, K., Del Ninno, C., Andrews C. \& Rodriguez-Alas C. 2013. Public Works as a Safety Net - Design, Evidence and Implementation. World Bank, Washington DC.

Zimmermann, L. 2014. Public works programs in developing countries have the potential to reduce poverty. Available at: <https://wol.iza.org/uploads/articles/25/pdfs/publicworks-programs-in-developing-countries-have-the-potential-to-reduce-poverty.pdf $>$ 